\title{
BOOKS IN REVIEW
}

Readers are reminded that suggestions of titles for review will be gladly received. Publishers are invited to send copies of works of bibliographical interest to the Review Editor. Reviews will be printed, whenever possible, in the language of the book under review: French or English. We shall be pleased to hear from subject specialists who are willing to review new publications in their field. Progress reports on works in preparation for the press are welcomed.

\section{WORK IN PROGRESS}

Although the second edition of the Bibliography of Canadian Bibliographies has just been issued from the press (see Reviews, below), the Council of the Bibliographical Society of Canada has already appointed a standing committee composed of Professor Douglas Lochhead (Massey College) and Mr. Peter Greig to carry on the work for future editions. Essentially, they will be examining procedures for maintaining, and adding to, the present master files. Any suggestions for improving the work, or of items for inclusion in future editions, will be welcomed by the members of the standing committee.

Les Journaux du Québec de 1764 à 1964 by André Beaulieu and Jean Hamelin (Québec: Les Presses de l'université Laval, 1965), already the envy of most other provinces, is being revised by the authors, and extended to include Quebec periodicals. Over 4,500 titles have been accumulated so far $(2,293$ in the original edition), and the work will appear in three separate volumes: vol. 1, to cover 1764-1859; vol. 2, 1860-1900; vol. 3, 1901 to date. The first volume is expected to be ready for the press (Laval) by the summer of 1972 .

The approximately 1,200 pages of the second edition of Dr. R.E. Watters's Check List of Canadian Literature and Background Materials, 1628-1960 are now completely proof-read, and are in the hands of the University of Toronto Press. Publication is scheduled for the summer of 1972 . The work is not only a revision and enlargement of the first edition but has also been extended a further decade, to include materials published up to 1960 . As a result, it will have at least 4,000 more titles. This new edition is already announced in the Spring and Summer Catalogue of the University of Toronto Press, at a price of $\$ 37.50$. It will be a monumental compilation, and we shall probably not see its like again, at least for a good many years.

Professor W.G. Richardson of Queen's University has completed the preliminary research for an annotated bibliography of the history of mining in Canada. Approximately 400 titles have been assembled, and sorting is now in progress. The author intends to include a detailed survey of the state of research into this aspect of Canadian history, with the hope of encouraging study in unexplored 
areas. The volume is expected to be ready for the press by September, 1972, but publication details are not yet settled.

A check list of the paperback publishing of John Ross Robertson, Toronto, 1870-1885, is now being prepared; it will include a chronological list of titles published, and an author and title index. The check list is being compiled by Professor Douglas Lochhead and Marian Press at Massey College Library. A preliminary edition will be issued, it is hoped, in the late fall of 1972.

That most useful and popular Guide to Scholarly Publishing in Canada, prepared for the Humanities and Social Sciences Research Councils by Penelope Williams (Ottawa, 1971), is already out of print. A new edition is taking shape in the hands of John Riddle, and it will be thoroughly revised as well as enlarged. Publication is expected in June, 1972.

Professor Gordon Elliott of Simon Fraser University's English Department is compiling "A Check List of Australian Literature and Background Materials held in Canadian Libraries to 1965 ". It is a gigantic task, and he is presently editing and filing some 50,000 entries reduced from twice that number accumulated by 1970. The manuscript will be produced from the edited entries, and Professor Elliott's aim is to have at least a draft manuscript ready by Christmas, and the finished bibliography by September, 1973. Fortunately, a sabbatical leave intervenes!

\author{
William F.E. Morley, Review Editor, \\ Douglas Library, Queen's University, \\ Kingston, Ontario
}

\title{
REVIEWS
}

Bibliography of Canadian Bibliographies/Bibliographie des bibliographies canadiennes. Comp. by Douglas Lochhead, index comp. by Peter Greig. 2nd ed., rev. and enl. Toronto: Published in Association with the Bibliographical Society of Canada by University of Toronto Press, 1972. xiv, 312 p. $\$ 20.00$. ISBN 0-8020-1865-3

If a bibliography is the key to the works on a subject or in a collection, then a bibliography of bibliographies is the key to all the subjects or collections in its field: indeed, in the case of Besterman's great work, of all fields. It is therefore a master key, which permits us to enter many doors. True, some are mighty archways, while others are garden gates; but bibliographies come in all sizes and even the most humble, if it does its job well, is quite properly included in a bibliography of bibliographies.

This new edition of Canada's own bibliography of bibliographies includes titles of books, pamphlets, articles, and theses, on an impressive variety of 